\title{
Colloquial in the Lyrics of Campursari Song by Cak Diqin
}

\author{
Fitriya Indriyani* \\ Javanese Language Education of Graduate School \\ Universitas Negeri Yogyakarta \\ Yogyakarta, Indonesia \\ fitriyaindriyani0@gmail.com
}

\author{
Endang Nurhayati \\ Javanese Language Education of Graduate School \\ Universitas Negeri Yogyakarta \\ Yogyakarta, Indonesia \\ endang_nurhayati@uny.ac.id
}

\begin{abstract}
This research attempts to examine the colloquial language in the lyrics of campursari song by Cak Diqin. The objectives are to reveal the unit, characteristics and function of colloquial language in the song. The research was designed with a qualitative method. The data were collected through listening and note taking techniques and validated using semantic validity and speech context, while the reliability was tested with reliability stability. The results show that the units of colloquial language in the song lyrics are word, phrase, clause, and sentence. The colloquial language in the song is characterized by expressions that contain idioms, incomplete lingual units especially the shortened words, rough language, and encouraging words. The colloquial language in the lyrics functions to express emotive, conative, referential, poetic, and fatic meanings.
\end{abstract}

Keywords: colloquial, lyrics of campursari song, Cak

Diqin

\section{INTRODUCTION}

Language is one of the cultural elements used as a communication mean to express one's thoughts and feelings. Due to the different social conditions of speakers, language varies. According to Kridalaksana (1978: 94) this is the domain of sociolinguistics research which investigates language characteristics related to the function of language variation in society.

One type of language variations is a colloquial language. According to Jendra (2012: 185), colloquial language is an informal language used in a relaxed situation. it is often called a habitual or daily language. Hence, a colloquial language is a language used to express intimacy like at home. One of the colloquial markers is an imperfect lingual unit, especially the abbreviation. Although it is abbreviated, people can understand what is meant. A colloquial variation is only found in informal circumstances. Therefore, a colloquial language can be seen as a peculiar variation.

The object of this research is the utterances or lyrics of Cak Diqin's campursari song. Colloquialism in the song lyrics is examined as the lyrics contain colloquial examples. colloquialism can only be found in informal utterances. each colloquial utterance has a different function depending on its context. This research discusses the lingual units, markers, and colloquial functions in the campursari song lyrics by Cak Diqin.

According to Chaer and Agustina (2004:2), sociolinguistics is an interdisciplinary science between sociology and linguistics. The relationship between language and socio-cultural conditions of the community can be seen from the variety and variations of the language used. Chaer and Agustina (2004:2) state that language variation can be divided into four variations based on its speakers, the use, formality, and means. The variation based on the speakers is divided into idiolects, dialects, cronolects, and sociolects. Sociolects can be further divided into acrolect, basilect, vulgar, slang, colloquial, jargon, argot, and ken.

According to Jendra (2012: 185), a colloquial language is a language variation that is often used in informal situations. According to Hymes in (Mulyana, 2005: 23), problems that affect utterance can be seen through the acronym SPEAKING. In this research the context is taken into account in order to reveal the problems and circumstances in the utterance. Jalalpour and Hossein (2017: 1013) state that colloquial languages are divided into three categories, words categories, phrases, and aphorisms. Aphorisms or proverbs are expressions that often use colloquial lingual units of clauses or sentences. Therefore, it can be concluded that the colloquial lingual units are word, phrase, clause, and sentence.

Richard and Schmidt in (Suhartinah, 2013: 12) state that a colloquial language is characterized by utterance in the forms of slang, idiom, and other language forms such as eliminating the subject or complementary verbs. McCrimmon through (Suhartinah, 2013: 14), states that one of the colloquial characteristics is the utterance that shows the use of the author's behavior. Whereas Jalalpour and Hossein (2017: 1013), opine that colloquial examples are abbreviated words as well as utterances that contain curses.

Examples of colloquial language that contains idioms:

Mr. Dewa : "Kowe kok njanur gunung le, kadingaren dolan mrene."

Tiko : "Inggih Pak."

The utterances above are used in a relaxed and informal situation by Mr. Dewa and Tiko when greeting each other, It's unusual for you to go to Mr. Dewa's house by using wangsalan. "Njanur gunung, kadingaren dolan mrene". This wangsalan means janur gunung: aren (sugar palm). In addition, the utterance also sounds colloquial.

According to Jacobson in (Suparno, 2013: 18) language functions are divided into six, emotive, conative, referential, poetic, fatigue, and metalingual. The colloquial functions in the Cak Diqin's campursari song lyrics are seen from the context. 


\section{METHOD}

This research used a descriptive research method to describe the lingual units, markers and colloquial functions in the campursari song by Cak Diqin. The data were obtained from all the utterances or song lyrics of Cak Diqin's campursari songs.

The research tool used was the human instrument in addition to a data card. The data were collected using the note-taking technique by listening to the song lyrics of Cak Diqin's Legendary Album 4, Lacosta 2, CJDW Cak Diqin Peduli Seniman, focusing on the colloquial expressions in the lyrics. The results of note-taking technique were transferred to a data card (Muhammad, 2011: 211).

The data validation was assured through semantic validity and the context of the utterance. The reliability was tested through stable reliability. The data were obtained by reading and analyzing repeatedly until the data were stable. The data are to be stable if the researcher has no doubt in determining lingual units, markers, and colloquial functions.

\section{RESULT AND DISCUSSIONS}

\section{A. Colloquial Lingual Word Unit}

1) Colloquial Lingual Word Unit with imperfect Lingual Unit Marker of Emotive Function

The following are examples of colloquial language at word level in the campursari song lyrics by Cak Diqin with emotive functions.

Context: Cak Diqin talked about the officials who were in prison.

Delengen kae, mlebu pakunjaran

Pejabat kang sawenang-wenang

(source: song Tuntunan dadi Tontonan)

The colloquialism "kang" belongs to the lingual unit of words as it can stand alone. The word is in an imperfect form because the word "kang" derives from the abbreviated word "ingkang". Based on the context, the word "kang" belongs to colloquial language as it is used in an informal situation when Cak Diqin complained to the interlocutor about officials who misbehaved. The above colloquialism contains an emotive function because it is used to describe annoyance as well as pleasure because the misbehaving officials have been in prison.

2) Colloquial Lingual Word Unit with Imperfect Lingual Unit Markers of a Conative Function

Below is an example of lingual unit markers that are imperfect with conative functions.

Context: Cak Diqin promised to the interlocutors that he would make a house and buy diamonds if he won a lottery.

Ja kuwatir yen nomerku nimbus tenan

Tak gawekke omah lan mundhut berlian

(source: song Cerewet)

The colloquialism above is the word "ja". The word "ja" is an abbreviated word from "aja". Based on the context of the utterance, the word "ja" is classified as a colloquial word because Cak Diqin spoke that way to the interlocutor as they are close in kinship; the conversation was in a relaxed context. The colloquial word also contains a conative function. Cak Diqin asked the interlocutors not to worry about living, because if he won the lottery, he would build a house and bought some diamonds. The word "ja" has a conative function, indicating a hope that the interlocutors should not worry or be sad.

3) Colloquial Lingual Word Unit with Imperfect Lingual Unit Marker of Referential Functions

The following is an example of colloquial lingual unit of word with a referential function.

Context: Cak Diqin's second child called him the Mister gambling, because he pawned the house certificate and it did not come back.

Nomer loro mister judi

Sertifikat mlebu gadhen ora bali

(source: song Koplak)

The colloquialism found in the song lyrics above is the word "gadhen". The word "gadhen" belongs to the lingual unit of word because it can function alone. The word is an imperfect lingual form because the word "gadhen" comes from the abbreviated word "pagadhean". Based on the context of the utterance, the word "gadhen" is colloquial because Cak Diqin used it in an informal and habitually situation when telling stories about his family. It has a referential function. Cak Diqin said that if his second son became a gambler, the pawned certificate would return. The word "gadhen" has a referential function because it refers to where the certificate is located in.

4) Colloquial Lingual Word Unit with Imperfect Lingual Unit Markers of Poetic Function

The following are utterances which are in imperfect forms with poetic functions.

Context: The interlocutor said that he preferred someone who is poor but whose love is pure rather than rich but often dishonest.

Nadyan sugih, nadyan sugih

Nadyan sugih gawene mung lara ati

Becik mlarat, becik mlarat

Becik mlarat becik mlarat tresnane suci

(source: song Nanting Rasa)

The colloquialism found in the lyrics of the song is the word "nadyan". The word "nadyan" belongs to a conjunction. It comes from the abbreviated word "senadyan". Based on the context of the utterance, the word "nadyan" is colloquial because it is spoken by the interlocutor when discussing personal matters. It also has a poetic function. The interlocutors talked about how choose a husband, either poor or rich. The word "nadyan" contains a teaching value in life or marriage, especially about how to choose a prospective husband.

5) Colloquial Lingual Word Unit with imperfect Lingual Unit Marker of Fatigue Function

Below is an example of colloquial word with a fatigue function.

Context: Cak Diqin told that the interlocutor should get to know the leader's behavior.

Tontonen kae dulur, yen pemimpine ngawur

(source: song Tuntunan dadi Tontonan)

The colloquialism found in the lyric is the word "dulur". The word "dulur" is a lingual unit because it can form a position. It is colloquial because it is characterized by 
incomplete lingual unit. The word "dulur" is derived from the word "sadulur". Based on the context, the word "dulur" is colloquial because it was used to know the corrupt leaders.

6) Colloquial Lingual Word Unit with mockery marker of Emotive function

The following is an example of Colloquial word with emotive function of curses.

Context: Cak Diqin insulted the shaman for making lots of noise to many people.

Dhukun cabul dhukun laknat, tobata moralmu bejat

Gawe kisruh bikin sesat

Dhukun cabul memang bangsat

(source: song Dhukun Cabul)

The colloquialism found in the song lyrics above is the word "bangsat". The word "bangsat" is a lingual unit of word because it can function alone. Based on the context of the utterance, the word is a colloquial word that contain a curse, because it is used to insult shamans whose behavior is not good. In addition, the word "bangsat" is used in a situation that is informal and relaxed for swearing.

The word bangsat is emotive in function as it is used to express feeling of annyance. Cak Diqin insulted the Shaman because of his bad behavior.

7) Colloquial Lingual Word Unit with Interjection Markers of Emotive Function

The following is an example of colloquial word an interjection marker that contain emotive functions.

Context: The interlocutor insulted Cak Diqin for being fussy by using a sarcastical word.

Tuku gedhang, tuku gedhang nggo pakan betet

He wong lanang, he wong lanang kakehan crewet

(source: song Mekekeh)

The colloquialism found in the song lyrics above is the word "he". The word "he" is classified as an interjection word because it can stand on its own and describe annoyance. Based on the context of the utterance, the word "he" is colloquial because the speaker used it to express annoyance. Its context of use is informal and relaxed because the thing discussed is personal. In addition, both interlocutors have a close relationship.

\section{B. Colloquial Lingual Phrase Unit}

Phrases are two or more combinations of word that have new meanings, but do not change the original meaning.

1) Colloquial Lingual Phrase Unit with Imperfect Lingual Unit Markers of Emotive Function

Below is an example of colloquial phrase with an emotive function.

Context: In this case, Cak Diqin is fine despite being betrayed by his partner.

Gandheng wong liya nyatane aku ra papa

(source: song Aku Rapapa)

The colloquialism found in the song lyrics above is the phrase "ra papa". It consists of the word "ra" as the core and the word "papa" as the attributive. The phrase is incomplete as the phrase "ra papa" derives from the shortened form "ora apa-apa". Based on the context of the utterance, the phrase "ra papa" is colloquial because it is used in an informal situation. It contains an emotive function. In this situation,
Cak Diqin tried hard to face the couple who betrayed him. The phrase "ra papa" contains an emotive function because it is used to express a sense of space.

2) Colloquial Lingual Phrases Unit with imperfect Lingual Marker of Conative Function

The following example is a colloquial phrase with a conative function.

Context: Cak Diqin could not return to his partner because the partner did not love him anymore.

Ra sah mrene sampean ra sah mrene

Cukup wae trisnaku cukup wae

(source: song Muspra)

The colloquialism found in the song lyrics above is the phrase "ra sah". It consists of the core "ora" and the attributive "usah". It is marked as incomplete because the phrase "ra sah" comes from the abbreviated "ora usah" phrase. Based on the utterance, the phrase "ra sah" is colloquial because it is spoken between interlocutors whose relation is close. It is conative in function used to express rejection.

3) Colloquial Lingual Phrase Unit with Bounding Markers of Emotive Function

The following is an example of colloquial phrase with an emotive function.

Context: Cak Diqin said that if many people came to shaman in the hope that their household would get along well them, but the reality would be the opposite.

Golek solusi neng dhukun

Rumah tangga ben dha rukun

Jabang bayik minta ampun

Dhukune matane rabun

(source: song Dhukun Cabul)

The colloquialism found in the lyrics of the song is "matane rabun". It consists of the core matane and the attributive rabun. It is colloquial used in an informal atmosphere for cursing by using harsh words. It is emotive in function used to insult and express sadness.

\section{Colloquial Lingual Clauses Units}

Below is an example of colloquial clause with a poetic idiom function marker.

Context: Cak Diqin said what is done is done.

Biyen mula sliramu wis tak aturi, golek bojo sing trisna welas sejati

Pungkasane sliramu digawe lara, ora wurung saikine dadi randha

Nanging piye kabeh mau wis kebacut, ibarat bubur ra bakal dadi sega

(sourcer: song Sida Randha)

The colloquialism found in the song lyrics above is the clauses "bubur ra bakal dadi sega". In the utterance, "bubur" as the chore and "ra bakal dadi sega" as the attributive. The clause is colloquial as it contains a proverb of moral value saying that what is done is done.

\section{Colloquial Lingual Sentences Units}

1) Colloquial Lingual Sentences Unit with Idiom Markers of Emotive Function

The following is an example of colloquial clause with an emotive function. 
Context: the speaker said something that insults the interlocutor for he is not handsome.

Dhasar wedhus wedhus dicathek asu

Rupa ra bagus prengus tidak bermutu

Apa pengin mangan pepesan sepatu

(source: song Mekekeh)

The colloquialism found in the song lyrics above is the sentence 1: "Dhasar wedhus wedhus dicathek asu". In sentence 1, "dhasar wedhus" is the core and "wedhus dicathek asu" is the attributive. In sentence 2, "Rupa ra bagus prengus tidak bermutu" is a clause, "Apa pengin mangan" is an attributive, and "pepesan sepatu" as the verbal.

the rest are utterances containing interjection. Sentence 1 is the modifier, while sentence 2 is the content. The colloquial sentence is emotive in function to express the annoyance of speakers for being insulted.

2 Colloquial Lingual Sentences Unit with Idiomatic Markers of Poetic function

The following is an example of colloquial clause with an emotive function.

Context: Cak Diqin expressed a poet about one who is loyal to the partner.

\section{Gedhang raja satundhun dipangan codhot \\ Timbang wurung aluwung guluku pedhot}

(source: song Gulu Pedhot)

The colloquialism found in the song lyrics above is "Gedhang raja satundhun dipangan codhot." and "Timbang wurung aluwung guluku pedhot." In sentence 1, "gedhang rajasatundhun" is the chore, and "dipangan codhot" as attributive. In the second sentence "timbang wurung" as the chore and "aluwung guluku pedhot"as the verbal.

These sentences include colloquials that contain idioms because they contain poetry in informal situations. Sentence 1 as modifier, while sentence 1 is the content. The colloquial above contains the poetic function, which contains the moral values about loyalty that must be fought for, towards the family, nation, country and utterance

\section{CONCLUSION}

Colloquial lingual units contained in Cak Diqin's campursari song lyrics are four, namely colloquial lingual words unit, colloquial lingual phrases unit, colloquial lingual clauses unit, and colloquial lingual sentences unit. The colloquial markers contained in Cak Diqin's campursari songs lyrics are four, which are marked by utterances containing idioms especially poets, imperfect lingual units especially abbreviated words, utterances containing curses, and

contains an interjection. The functions are emotive, conative, referential, poetic, and fatigue functions. The colloquial function can be seen by looking at the context.

\section{REFERENCES}

Chaer, Abdul and Leonie Agustina. 2004. Sosiolinguistik Perkenalan Awal. Jakarta: Rineka Cipta.

Jalalpour, Elham and Hossein. 2007. "A Study of English Translation of Colloquial”. Gale Cengage Learning, 5, pp. 1011-1021.

Jendra, Made Iwan Indrawan. 2012. Sociolinguistics Study of Societies' Languages. Yogyakarta: Graha Ilmu.

Kridalaksana, Harimurti. 1978. Sosiolinguistik dalam Leksikografi. Tugu: Panitia Penataran Leksikografi (Language Center)

Muhammad. 2011. Metode Penelitian Bahasa. Yogyakarta : Published by Ar-Ruzz Media

Mulyana. 2005. Kajian Wacana. Yogyakarta: Tiara Wacana.

Suhartinah, Tri Utari. 2013. Bahasa Inggris Kolokial pada Chicklit Mini Shopaholick karya Shopie Kinsella. Thesis S2. Yogyakarta: Program Studi Linguistik, FIB Universitas Gadjah Mada.

Suparno. 2013. Dasar-dasar Linguistik Umum. Yogyakarta: Tiara Wacana.

The VCD of Campursari by Cak Diqin in Album Legendary 4 which was relased in 2014 produced by Tirta Arum Record

The VCD of Campurdangdut by Cak Diqin in Album Lacosta 2 which was relased in 2015 produced by Tirta Arum Record

The VCD of Campursari by Cak Diqin in Album CJDW Cak Diqin Peduli Seniman which was relased in 2012 produced by CV. Riwayat Elektro Musik. 